\title{
TORT LIABILITY IN GERMAN SCHOOL LAW*
}

\section{RaLph Dornfeid Owen†}

At the outset, it should be stressed that in spite of three great changes in the form of its national government the legal system of Germany has undergone no radical change since $1900 .^{I}$

In its broadest sense, the concept of tort liability is common to the legal systems of the United States and Germany. It is well stated in Section 823 of the German Civil Code (Bügerliches Gesetz-Buch [abbreviation-B.G.B.]), ${ }^{2}$

Whoever knowingly or negligently injures the life, body, health, liberty, property, or any right of another person illegally is liable for the injury.

Again, the legal systems of both countries recognize the principle of "respondeat superior" or "let the superior answer for his subordinate," which is also called the master-servant principle. Thus, if an employee in performing the duties assigned to him, injures the person, property, or rights of another, the liability falls, not upon him, but upon his employer. This is stated in the German Civil Code (B.G.B.), Section $83 x^{3}$,

Whoever employs another person to work under his direction is liable for any injury which the latter in performing his work may illegally inflict upon a third party.

At this point, however, German legal thinking and ours diverge. In the United States, our courts generally hold that if the employer is the state, he is free from the obligation implied by "respondeat superior." Why? Because the courts hold that the medieval English principle, "the King can do no wrong," has been passed on down to each individual state of the Union. Furthermore, the courts hold that it applies to every subdivision of the state, so that even the tiniest school district enjoys "sovereign immunity" from liability for tort.

This is well illustrated by a case where an employee of a state agricultural college was injured by a defective pump and spray. The Texas court declared that common law does not "obligate a state to forego its sovereign authority not to be bound as a private employer. ..." The court also pointed out that the "state is not liable for the torts or negligence of its officers, agents, or servants, engaged in the performance

* The writer takes pleasure in acknowledging his indebtedness to the Hochschule Für Internationale Pädagogische Forschung in Frankfurt am Main, where he collected material for this article. He is particularly grateful to Dr. Werner Küchenhoff, to Dr. Hans Heckel, and to the library staff, for making his visit both pleasant and profitable.

+Professor of Education, Temple University, 1929-1954; Fulbright visiting professor, Pädagogische Seminar, University of Marburg.

${ }^{1}$ Gustav Tiemann et al., Die Amtsführung des Lehrers 69 (Düsseldorf, Paegogischer Verlag Schwann, 195 I).

"Otto Palandt, Bürgerliches Gesetzbuch und Kommentare (Munich and Berlin, ioth ed. 1952).

Ibid. 
of a governmental function unless it [the state] has expressly assumed such liability [through legislative action]."4

In contrast, consider the language of the German Civil Code (B.G.B.) : ${ }^{5}$

When an official, in the performance of his official duty and authority, injures a third person, the liability rests primarily upon the state, or the subdivision of the state which employed him. The state has the right to proceed against him by regular court procedure.

Since the public school teacher takes an oath of office and is considered a public official, the preceding article applies to him.

The School Code (Kultusrecht) of the Federal Republic declares: ${ }^{6}$

The state must recognize the rights of the child who is under legal compulsion to attend school. The state must provide the requisite conditions for the child to comply with the attendance law.

These are the following:

(a) organized school life, with adequate buildings, playgrounds, and activities,

(b) sufficient numbers of qualified teachers,

(c) free instructional supplies,

(d) free tuition in the elementary school,

(e) financial subsidies to pupils, ten years old or more, whose ambition, capacity, and achievement warrant them,

(f) well planned program of health and recreation,

(g) assuming responsibility for children's accidents, occurring on the way to school, at school, or in school activities. (Italics supplied.)

It is clear that for about fifty years German law has recognized that an implied contract exists between the state and the child or its parent. It says, "Since we require the child to attend school regularly, we will protect him from injury." Let us call this Principle Number One concerning tort liability in German School Law.

But there is another provision in German civil law which helps to protect the child attending school. That is what has been called the "Safe Place" Law. Section 836 of the Civil Code (B.G.B.) provides: ${ }^{7}$

When, as a result of the collapse of a building or any other structure connected with a piece of ground, or of the breaking off of parts of the building or structure, a person is killed, or his body or health is injured, or a thing belonging to him is injured, the owner of the piece of ground is liable to the extent that the collapse or breaking was the result of defective construction or of inadequate maintenance. He is not liable if he exercised due diligence to prevent such accidents.

Again, the term "owner" applies equally to individuals and the state. Sections $3^{I}$ and 89 of the Civil Code (B.G.B.) declare that the state, cities, rural communities,

\footnotetext{
4 State v. Morgan, I7o S.W.2d 652, 654 (Texas Comm'n of Appeals, I943). See Joseph Sattrerfield and Ralph Dornfeld OWen, The Teacher Pays i6 (I95I).

¿ Paland, op. cit. supta note 2.

- Education, I Purpose and Structure of Common School, \$I, par. 7(2)(a) to (g), GRAPENGETER AND O. von Zersen, KultusRecht des Bundes (Hamburg, I953).

'PALANDT, op. cit. supra note 2.
} 
townships ("Kreise"), school districts, school societies, and other societies, incorporated or unincorporated, all are liable for any injury suffered by a third party because of the illegal act (i.e., neglect) of its officers, its board of trustees, or any authorized representative thereof (e.g., the school principal). ${ }^{8}$

Let us illustrate it in this way: John Wanamaker, Inc., owes no protection to a trespasser entering its grounds or buildings, but it does owe diligent care to protect its "invitees," the customers. Likewise, the state or the city owes diligent care to protect everyone who has occasion to enter upon its grounds or its buildings. But the state or the school district owes an even greater measure of diligence to protect its "compulsees," the children who nolens volens must enter the school grounds and buildings. Let us call this Principle Number Two concerning tort liability in German School Law. German School Law imposes great responsibility upon the school principal and the classroom teacher. Both definitely stand in loco parentis. This is emphasized in the following law of the Federal Republic, ${ }^{\circ}$

Whoever has the responsibility of exercising supervision over a person under the age - of eighteen and neglects to exercise it properly makes himself liable to six months imprisonment or a monetary fine, if his charge commits an unlawful act which he could have prevented through appropriate supervision.

The prosecution can be initiated only by the appropriate agency [i.e., the school by which the supervisor is employed].

The writer now presents summaries of some tort liability cases decided by German courts since 1930 .

Case No. $I^{10}$

The teacher of a primary class had left the room for a few minutes and had appointed two thirteen-year old girls from another class to supervise her pupils. Someone dropped a pen and holder. Three young girls tried to pick it up and got into a scuffle over it. A seven-year old girl was struck in the eye with the pen. The eyeball was pierced and she lost the sight of her left eye.

Her parents brought suit against the state, contending that there had been lack of adequate supervision. On appeal, the case went to the supreme court of the state (Oberlandesgericht [abbreviation-O.L.G.]). Arguments were heard and the decision was handed down on December 8, I937, declaring that there had been no neglect of supervision.

\section{Case No. $2^{11}$}

On September I2, I95I, a class of pupils, comprising grades I to III, was to report at school at ro o'clock in order to observe National Memorial Day. Several children arrived on the school grounds at 9 o'clock, before the teacher's official duty of supervision began.

\footnotetext{
Ibid.

'I Reichs Gesetz Blätter 1336; Tiemann, op. cit. supra note I, at 65.

${ }^{10}$ Reported in 4 Deutsche Wissenschaft, Erziehung, und Volksbildung 13 (Berlin, 1938).

11 Reported in Die Schileswig-Holsteinische Schule 13 (Jan. 1952).
} 
About 9:30, Pupil $A$ of the grade III level was playing at an incompleted fence (concrete posts with iron pipes running through them). He put his lips to the end of a pipe to shout through it. Pupil $B$ of the same grade level, running backwards, struck Pupil $A$ so hard that he broke a front tooth.

The mother of Pupil $A$ asked the father of Pupil $B$ to pay for an artificial tooth. The latter refused. Subsequently, she brought suit against the state, claiming damages and contending that the accident was caused by lack of supervision. The court rejected her claim, because (I) the official supervision period did not begin until twenty minutes after the accident, and (2) the accident could have happened even if the teacher had been on the grounds.

The court further pointed out that she could sue the father of Pupil $B$, because at the moment of the accident Pupil $B$ was under the supervision of the father. It cited Section 832 of the Civil Code (B.G.B.).

$$
\text { Case No. } 3^{12}
$$

During the main recess in a rural school, there were fifty or sixty children playing on the school grounds. A group of boys engaged in a game of running and catching. A boy aged twelve fell and broke his thigh. Unfortunately, the teacher in charge of supervision had just gone away for a few moments to speak to the principal.

The father brought suit against the state, demanding $530 \mathrm{DM}$ for medical care. His contention was that (I) the temporary absence of the teacher constituted neglect of duty on the teacher's part and contributed to the accident, and (2) the school board was guilty of neglect because it had not seen to it that the grounds were perfectly level.

The lower court (Landgericht) rejected his plea. He appealed to the higher court (Oberlandesgericht). The latter held that the teacher deserved censure for leaving the grounds but that neither this fact nor the unevenness of the ground could be blamed for the accident.

$$
\text { Case No. } 4^{13}
$$

Mr. $N$., teacher in an elementary school in Munich, had a class of boys between the ages of thirteen and fourteen. He found it necessary to leave the classroom for a short time on an official matter. He placed Pupil $M$ in charge. During his absence, Pupil $K$ shot a piece of metal with a rubber band. It struck Pupil $D$ in the right eye with the result that he lost the eye.

Pupil $D$, through his father, brought a civil suit against Pupil $K$. The lower court (Landgericht) at Munich allowed him 2000 DM for medical costs and held Pupil $K$ liable for future payments to indemnify Pupil $D$ for vocational handicaps that might result from the loss of his eye.

Pupil $D$ also brought suit against the state, contending that the teacher had been

${ }^{23}$ Reported in Hessische LehrerzeItung 158 (June 15,1953 ).

${ }^{13}$ Reported in Die Bayrische Schule (Jan. 15, 1954). 
guilty of neglect of duty in leaving the room without getting another teacher to take his place. Testimony, however, indicated that in general the class was well behaved. The court exonerated the teacher.

\section{Case No. $5^{14}$}

A teacher took his class from the schoolhouse to a church in the center of town. Before starting out, he had admonished them to be careful. They marched by two's. At a busy intersection, he led the line across the street. While he was doing this, two boys at the rear began to scuffe, so that one of them was thrown against an old woman, knocking her down and breaking her thigh.

The woman brought suit against the state, contending that the teacher had been negligent. The lower court (Landgericht) at Munich rejected her claim. She appealed to the higher court (Oberlandesgericht). In the hearing of testimony, it became evident that the teacher had exercised all reasonable care. The court rejected her suit.

\section{Case No. $6^{15}$}

In a school in Westphalia, the janitor had spread coal ashes and cinders to level up some depressions in the surface of the school grounds. Pupil $A$ teased Pupil $H$. The latter picked up a lump of cinder and threw it at Pupil $A$, causing a bad gash. The mother of Pupil $A$ brought suit against the state, charging neglect of duty on the part of the teacher and the school board, because:

(I) the teacher had stood near the door of the schoolhouse, instead of being near the center of the grounds;

(2) the principal had taught the children that they must not throw objects, such as stones, at others; and

(3) the school board had not taken out accident insurance for the benefit of the pupils.

The lower court (Landgericht) rejected her arguments. She appealed to the higher court (Oberlandesgericht) at Hamm. The latter, in rejecting her appeal, declared that:

(x) the accident could have happened even if the teacher had been near the center of the playground;

(2) the teacher has the right to assume that parents, who have control over a child before he enters school and share in his supervision during school years, have taught their child, before he is admitted to school, that he must not throw stones at other persons; and

(3) according to school law, the school board may use its discretion whether or not it will take out accident insurance for its pupils.

\footnotetext{
14 Reported in Die Bayrische Schule (Apr. 15, 1954).

${ }^{16}$ Reported in SchulbiatT Für DEN REgierungsbezirk DetMold (Dec. 195I); reprinted in Wirtschaft uND Recht, SUPplement to Neue Deutsche Schule 2 (Feb. 1952).
} 
Case No. $7^{16}$

On May 16, r951, there took place on a Sport Field a football game between two amateur clubs. Horst $X$, not quite sixteen, was a participant. It was a humid day. During the first half there was a shower. About ten minutes after the beginning of the second half, lightning struck so near that all the players were knocked down. The referee called the game off.

After all the other players had arisen, they found that Horst was dead. A medical expert testified at the coroner's inquest that the lightning had passed between the second and third toes of Horst's right foot. This excluded the possibility of his having died from overexertion in the humid weather.

The state's attorney set up an investigation to determine whether the referee had been guilty of negligence-specifically, whether he should have canceled the game because of the threatening weather (under section $c$ of the football rules).

Since he could not foresee the electric storm and did call off the game when the storm began, he was exonerated of having violated the federal law [I Reichs Gesetz Blätter 1336$]$ concerning supervision over persons under the age of eighteen.

Case No. $8^{17}$

On July I4, I950, Mr. N., an elementary teacher in Berlin, took his IV B class on an outing to the Pfauen Island (literally-"Peacock's Island"). Before setting out, he explained to his pupils what he expected of them and stressed that they must remain together. After visiting the island, they sat on the opposite shore and some of the pupils were swimming. Mr. $N$. put on his swimming suit and stood in the water, further out than the swimmers, to serve as a life guard. Finally, he ordered them all ashore and called the roll. All were present. Since most of the youngsters who had gone into the water had no towels, he took them on a short, brisk walk through the woods.

The teacher led the way. Pupil $H$ was at the rear and as soon as he could he returned to other pupils sitting near the water. He took a coin out of his clothes and told them that he was going to buy himself some ice cream.

When Mr. $N$. returned, he called the roll and found that Pupil $H$ was missing. He called the police for aid. They could not find the boy. Three days later the river police found his body. The state's attorney (coroner) issued a burial permit.

Later, the parents brought a civil suit against Mr. $N$., accusing him of negligent supervision. The Teachers Association helped defend him. He was exonerated. Next the parents brought a criminal suit against Mr. $N$. with the intent of making the state responsible, under Sections I 43 and I70 of the Criminal Code. But on January $3 \mathrm{I}$, I952 the court (Landgericht) acquitted him.

${ }^{10}$ Reported in 2 RECHT DER JUGEND (NO. 5I) (March, 1954).

${ }^{17}$ Reported in Recht und Jugend Igi-rg2 (June, 1954). 
Case No. $9^{18}$

A class in the school for the blind in Munich had been receiving instruction in swimming for several months. One day the teacher took the class to Pilsen Lake. Pupil $A$ went into the water with an older boy. The beach sloped gently. When he could no longer touch bottom, he clasped his hands about the neck of the older boy, who carried him out further. When they reached the place where the taller boy could no longer touch bottom, he turned around and headed back. Suddenly, Pupil $A$ let go and, without so much as an outcry, sank. The teacher had been watching the two all along.

The mother of the boy brought suit against the state. Expert medical testimony showed that the boy had not drowned but had had an acute heart attack. The lower court exonerated the teacher of negligence. The mother appealed to the higher court (Oberlandesgericht) at Munich, but her appeal was rejected.

Case No. $10^{19}$

During the summer of 1949 , Gerda Brauschke, then thirteen, was a pupil in an elementary school. On June 24, 1949, during the forenoon recess, she and two other girls were sitting on a pile of lumber. Several boys, among them Heinrich Meyer, grabbed another boy, Willi Wenzel, by his arms and feet and dragged him to where the girls were sitting and tried to toss him on the girls' laps. Gerda and another girl saw this in time to jump up and avoid it. Willi landed on the lap of the third girl. She pushed him off, jumped up, and slapped the ear of the ringleader Meyer. He turned around, saw Gerda, and kicked her in the abdomen. Gerda had to be taken home, and she spent a month in bed. On July 26 , she was admitted to a hospital, where a thorough examination revealed that she had developed diabetes.

Through her father she brought suit against the State of Hesse to recover damages for the injuries suffered and for medical care. She contended that at the time of the accident there was no teacher on the playground, and that the physical injury had caused her diabetes.

Counsel for the state contended that (I) supervision had been assigned to a Mrs. Wagner, who arrived on the scene shortly after the accident; (2) it might have happened even if she had arrived earlier; and (3) the kick could not have brought on diabetes.

Testimony by the girls and other pupils brought out the fact that the teacher assigned to supervise the grounds had had a double assignment, first to supervise the dismissal of three classes, then to supervise the grounds. It also showed that the school principal and another male teacher had stood at the front door and had paid no attention to the grounds. In fact, when one of Gerda's companions ran to them and reported the accident, they told her to go to see the teacher in charge.

The judgment of the court was that the principal was guilty of neglect; the

${ }^{18}$ Reported in Hessische Lehrerzertung (June I, r954).

${ }^{10}$ Official transcript of Brauschke v. State of Hesse, Civil Court at Kassel, Nov. 13, I95I. 
state, being responsible for the safety of the pupils, must pay a suitable amount for Gerda's suffering and I400 DM for medical costs.

The State of Hesse appealed to the Higher Court in Kassel. Oral arguments were heard. The medical experts for the state asserted that diabetes could not be caused by a physical injury such as Gerda's. Counsel for Brauschke countered with expert testimony that more recent research had proved the contrary.

On December 9, x952, the court rejected the appeal of the State and confirmed the judgment of the lower court in favor of Gerda Brauschke. 